\title{
OPEM
}

www.opem.org

Oriental Pharmacy and Experimental Medicine 2009 9(3), 225-231

DOI 10.3742/OPEM.2009.9.3.225

\section{Hepatoprotective and free radical scavenging activities of Lagerstroemia speciosa Linn. leaf extract}

\author{
Priya Thambi, Mandumpal Chacko Sabu and Jolly Chungath* \\ Amala Cancer Research Centre, Amala Nagar, Thrissur, Kerala, 680 555, India \\ Received for publication May 16, 2008; accepted March 13, 2009
}

\begin{abstract}
SUMMARY
The present study deals with the amelioration by Lagerstroemia speciosa Linn. leaf extract against hepatotoxicity induced by carbon tetrachloride $\left(\mathrm{CCl}_{4}\right)$, which was evaluated in terms of serum marker enzymes like serum glutamate pyruvate transaminase, serum glutamate oxaloacetate transaminase, alkaline phosphatase, serum total bilirubin, total protein levels along with concomitant hepatic and antioxidants like superoxide dismutase, catalase, glutathione, glutathione peroxidase and lipid peroxidation enzymes were monitored. These biochemical parameters altered by the single dose level of $\mathrm{CCl}_{4}(0.75 \mathrm{ml} / \mathrm{kg}$ body weight, i.p). Pre treatment with $\mathrm{L}$. speciosa prior to the administration of $\mathrm{CCl}_{4}$, at the doses of 50 and $250 \mathrm{mg} / \mathrm{kg}$. body weight/day, p.o. for 7 days, significantly restored all the serum and liver tissue parameters near to the normal levels, respectively. Silymarin was used as a reference standard, prior to the administration of $\mathrm{CCl}_{4}$ to rats. These findings indicate the protective potential of L. speciosa against hepato toxicity which possibly involve mechanism related to its ability of selective inhibitors of (reactive oxygen species like antioxidants brought about significant inhibition of TBARS suggesting possible involvement of $\mathrm{O}_{2}{ }^{-}, \mathrm{HO}_{2}{ }^{\circ}$, and $\cdot \mathrm{OH}$. In conclusion, the amelioration may be attributed to the synergistic effects of its constituents rather than to any single factor as the leaves are rich in tannins, sterols, flavonoids, saponins etc.
\end{abstract}

Key words: Lagerstroemia speciosa; Hepatoprotective activity; Antioxidant

\section{INTRODUCTION}

Lagerstroemia speciosa Linn. is a tropical plant, whose leaves have been used as a folk medicine for the treatment of diabetes and kidney diseases (Liu et al., 2001). The role of free radicals and antioxidants in the pathogenesis of human diseases and in the process of ageing has led to the suggestion that antioxidants, in particular plant derived antioxidants, may have health benefits as prophylatic agents.

*Correspondence: Jolly Chungath, Amala Cancer Research Centre, Amala Nagar, Thrissur, Kerala, 680 555, India. E-mail: priyasabu@rediffmail.com
(Diadelis et al., 2005). It is also used for abdominal pains, mouth ulcers, stimulant and febrifuge (Kirthikar and Basu, 1987) The extract of this plant is reported earlier as an antioxidant and as nephroprotective agent (Priya et al., 2007).

Numerous medicinal plants and their formulations are used for liver disorders in ethnomedical practices as well as in traditional systems of medicines in India (Subramoniam et al., 1998) Hepatic fibrosis is a common condition in which major amounts of liver parenchyma cells are replaced by fibrous connective tissue. Liver diseases remain one of the serious health problems and it is well known that 
free radicals cause cell damage through mechanisms of covalent binding and lipid peroxidation with subsequent tissue injury (Babu et al., 2001). Experimentally hepatic fibrosis is formed by the administration of $\mathrm{CCl}_{4}$, paracetamol, thioacetamide etc. Scavenging of free radicals by antioxidants could reduce the fibrosis process in the tissues. It has been stated that one of the principal causes of $\mathrm{CCl}_{4}$ induced hepatopathy is lipid peroxidation by $\mathrm{CCl}_{3}$, a free radical derivative of the toxin (Bishayee et al., 1995). In this study we report on the protective effect of $L$. speciosa ethanol extract against hepatotoxin $\mathrm{CCl}_{4}$. The literature reviews indicated the antidiabetic activity of L. speciosa leaf ethanol extract, but the hepatoprotective activity has not been clinically evaluated so far. Hence the present study has been undertaken to investigate the antioxidant and hepatoprotective activity of leaf extracts of L. speciosa $\mathrm{CCl}_{4}$ induced hepatotoxicity in rats.

\section{MATERIALS AND METHODS}

\section{Plant materials}

The leaves of Lagerstroemia speciosa Linn were collected from Amala Ayurvedic Hospital premises, Thrissur. Dr. Sunil CN, Department of Botany, S.N.M College, Maliankara, Kerala, authenticated it and a voucher specimen (BSI No. 62373) was kept at Fr. Gabriel Herbarium, Amala Ayurvedic Hospital, Thrissur. The powdered leaves were subjected to successive soxhlet extraction using a series of solvents of increasing polarity starting from petroleum ether, ethyl acetate, ethanol, methanol and water respectively. The extracts were vacuum dried and the percentage yields of the extracts were 3.56, 4, $14.2,3.19$ and $17.47 \%$ respectively.

\section{Animals}

Female Balb/c mice (20 - $25 \mathrm{~g}$ ) and male Wistar rats weighing (150 - $200 \mathrm{~g})$ were purchased from small animals breeding station, College of Veterinary and Animal Science, Mannuthy, Thrissur. The animals were housed in polypropylene cages in air-conditioned room at $25 \pm 2^{\circ} \mathrm{C}$ with a $10: 14 \mathrm{~h}$ light and dark cycle and maintained with standard feed (Lipton India, Ltd) and water ad libitum. All animal experiments conducted during the present study prior permission from Institutional Animal Ethics Committee (IAEC) and followed the guidelines of IAEC.

\section{Phytochemical analysis}

Chemical tests were carried out to identify the phytoconstituents present in the successive extracts (Harborne, 1998).

\section{Acute toxicity}

The test was carried out as suggested by Seth $e t$ al. (1972). Mice were divided into eight groups of six animals each. The control group received normal saline ( $2 \mathrm{ml} / \mathrm{kg}$, p.o.) The other groups received $100,200,400,800,1,000,2,000,3,000 \mathrm{mg} / \mathrm{kg}$ of the ethanol extract, respectively. Immediately after dosing the animals were observed for their behavior continuously for the first $4 \mathrm{~h}$. They were kept under observation up to 14 days after extract administration to find out the mortality and body weight was observed.

\section{Hepatoprotective activity of the extract against acute $\mathrm{CCl}_{4}$ toxicity.}

Male Wistar rats weighing (150 - $200 \mathrm{~g})$ were divided into four groups containing six animals per group. (Senthilkumar et al., 2005) The first group was kept as normal group. The second group was kept as an untreated control. The third group was administered with the standard drug, silymarin. The fourth and fifth group was treated with ethanol extract of L. speciosa (50 and $250 \mathrm{mg} / \mathrm{kg}$ body weight) for seven days prior to $\mathrm{CCl}_{4}$. The second, third, fourth and fifth groups were given $\mathrm{CCl}_{4}$ administration in paraffin oil (1:1) $72 \mathrm{~h}$ after the $\mathrm{CCl}_{4}$ injection, animals were sacrificed. Blood was collected by heart puncture of each animal. Serum was used for the determination of glutamate oxaloacetate transaminase (GOT), glutamate pyruvate transaminase (GPT) (Reitman and Frankel, 1957), 
alkaline phosphatase (ALP), (King, 1965) Bilirubin (Malloy and Evelyn, 1937), protein, albumin. (Span Diagnostics Ltd) and serum lipid peroxidation (Satoh, 1978).

\section{In vivo antioxidant activity}

After the treatment period, the animals were deprived of food overnight and sacrificed by cervical dislocation. The livers were dissected out, washed thoroughly in ice-cold saline, patted dry and weighed. A $10 \% \mathrm{w} / \mathrm{v}$ of homogenate was prepared in PBS (50 mM, pH 7). The homogenate was used for the estimation of lipid peroxidation (LPO) (Ohkawa et al., 1979). A part of homogenate after precipitating proteins with trichloro acetic acid (TCA) was used for estimation of reduced glutathione (GSH) (Moron et al, 1979) and glutathione peroxidase (GPx) (Paglia and Valentine, 1967). The rest of the homogenate was centrifuged at 15,000 rpm for $15 \mathrm{~min}$ at $4^{\circ} \mathrm{C}$. The supernatant thus obtained was used for the estimation of superoxide dismutase (SOD) (McCord and Fridovich, 1969) and catalase (CAT) activity (Aebi, 1983). Tissue protein was determined by the method of Lowry et al. (1951).

\section{Statistical analysis}

Experimental data were expressed as mean \pm SD. Dunnett's $t$-test was applied for expressing the significance and $P$ value less than 0.01 was considered as significant.

\section{RESULTS}

The preliminary phytochemical analyses of the successive extracts indicate the presence of alkaloids, tannins, saponins, flavonoids, steroids and glycosides in L. speciosa (Table 1). In acute toxicity study, it was found that the extract induced sedation and temporary postural defect at all tested doses. However, there was no mortality at any of the tested doses till the end of 14 days of observation.

\section{Hepatoprotective activity of the extract against acute $\mathrm{CCl}_{4}$ toxicity}

The activities of SGPT, SGOT and ALP of animals seventy-two hours after the acute intoxication of $\mathrm{CCl}_{4} /$ paraffin oil are summarized. The results indicated the activity of SGOT, SGPT and ALP were significantly enhanced by $\mathrm{CCl}_{4}$ injection. The concomitant treatment of $\mathrm{CCl}_{4}$ with ethanol extract of L. speciosa at 50 and $250 \mathrm{mg} / \mathrm{kg}$ resulted in significant decrease of SGOT and SGPT activity when compared with the control. However the effect was better at $250 \mathrm{mg} / \mathrm{kg}$ treatment. The activity of serum ALP in the extract treated groups was also significantly reduced $(P<0.01)$ compared to the $\mathrm{CCl}_{4}$ - treated control group. The treatment of the leaf extract showed significant reduction in the elevated level of serum bilirubin also (Tables 1 and 2).

\section{In vivo antioxidant status}

The activities of all the antioxidant enzymes were

Table 1. Qualitative phytochemical evaluation of the Lagerstroemia speciosa extracts

\begin{tabular}{|c|c|c|c|c|}
\hline \multicolumn{5}{|c|}{ Observation } \\
\hline Phyto Constituents & Ethyl acetate & Ethanol & Methanol & Water \\
\hline Saponins & - & + & + & + \\
\hline Tannins & + & + & + & + \\
\hline Alkaloids & - & - & + & + \\
\hline Sterols & + & - & + & + \\
\hline Glycosides & - & + & - & - \\
\hline Flavonoids & + & + & + & - \\
\hline Reducing sugars & + & - & + & + \\
\hline
\end{tabular}

'+' and '-' indicates the presence and absence of the active constituents. 
Table 2. Effect of ethanol extract (EtOH) of L. speciosa on serum SGOT, SGPT and ALP activities in rats with acute $\mathrm{CCl}_{4}$ administration

\begin{tabular}{ccccc}
\hline Groups & Treatment $(\mathrm{mg} / \mathrm{kg})$ & SGPT $(\mathrm{IU} / \mathrm{l})$ & SGOT $(\mathrm{IU} / \mathrm{l})$ & ALP $(\mathrm{IU} / \mathrm{l})$ \\
\hline Normal & Vehicle & $123.78 \pm 6.73^{* *}$ & $142.616 \pm 6.12^{* *}$ & $14.5 \pm 3.49^{* *}$ \\
Control & $\left(\mathrm{CCl}_{4} /\right.$ Paraffin oil, $\left.1: 1\right)$ & $790.3 \pm 21.5$ & $236.21 \pm 10.5$ & $42.15 \pm 8.77$ \\
$\mathrm{EtOH}+\mathrm{CCl}_{4}$ & 50 & $567.2 \pm 16.13^{*}$ & $217.19 \pm 7.43$ & $34.13 \pm 2.45$ \\
$\mathrm{EtOH}+\mathrm{CCl}_{4}$ & 250 & $382.5 \pm 10.18^{* *}$ & $162.5 \pm 7.6^{*}$ & $27.76 \pm 2.94^{*}$ \\
Silymarin $+\mathrm{CCl}_{4}$ & 100 & $158.70 \pm 8.69^{* *}$ & $154.41 \pm 6.5^{* *}$ & $20.36 \pm 2.18^{* *}$ \\
\hline
\end{tabular}

${ }^{* *} P<0.01,{ }^{*} P<0.05$ (Dunnett's $t$-test) significantly different from control group. Values are mean \pm S.D., $\mathrm{n}=6$ animals, Serum glutamate pyruvate transaminase (SGPT), Serum glutamate oxaloacetate transaminase (SGOT), Alkaline phosphatase (ALP).

Table 3. Effect of ethanol extract $(\mathrm{EtOH})$ of L. speciosa on total Bilirubin, and Total protein level in rats with acute administration

\begin{tabular}{lccc}
\hline Group & Treatments $(\mathrm{mg} / \mathrm{kg})$ & Total Bilirubin $(\mathrm{mg} / \mathrm{dl})$ & Total Protein $(\mathrm{gm} / \mathrm{dl})$ \\
\hline Normal & Vehicle & $0.53 \pm 0.04^{* *}$ & $7.86 \pm 2.40^{* *}$ \\
Control & $\left(\mathrm{CCl}_{4} /\right.$ Paraffin oil, $\left.1: 1\right)$ & $8.05 \pm 0.08$ & $3.74 \pm 1.21$ \\
EtOH $+\mathrm{CCl}_{4}$ & 50 & $1.98 \pm 0.09^{* *}$ & $3.98 \pm 1.9$ \\
EtOH $+\mathrm{CCl}_{4}$ & 100 & $0.75 \pm 0.07^{* *}$ & $5.23 \pm 2.1^{* *}$ \\
Silymarin $+\mathrm{CCl}_{4}$ & 100 & $0.51 \pm 0.05^{* *}$ & $6.89 \pm 2.01$ \\
\hline
\end{tabular}

${ }_{* *} P<0.01$, (Dunnett's $t$-test) significantly different from control group. Values are mean \pm S.D., $\mathrm{n}=6$.

significantly $(P<0.01)$ restored to almost normal level in animals administered with extract $(250 \mathrm{mg} / \mathrm{kg})$ prior to $\mathrm{CCl}_{4}$ treatment. In vivo lipid peroxidation levels showed that the $\mathrm{CCl}_{4}$ administered group showed significant increase $(P<0.01)$ in malondialdehyde (MDA) level both in liver tissue and serum when compared with normal group. The level of MDA formed was decreased dose dependently by the administration of ethanol extract of $L$. speciosa. The $\mathrm{SOD}$ activities in the $\mathrm{CCl}_{4}$ plus extract (50 and $250 \mathrm{mg} / \mathrm{kg}$ body weight) treated groups were $5.602 \pm 0.83$ and $8.339 \pm 1.208 \mathrm{U} / \mathrm{mg}$ protein. Similarly the activity of catalase in the $\mathrm{CCl}_{4}$ aloneinjected animals was $11.928 \pm 2.316 \mathrm{U} / \mathrm{mg}$ protein and in the extract (50 and $250 \mathrm{mg} / \mathrm{kg}$ body weight) plus $\mathrm{CCl}_{4}$ treated animals were $12.736 \pm 2.22$ and $21.912 \pm 1.465 \mathrm{U} / \mathrm{mg}$ protein. The activity of GPx in the extract (50 and $250 \mathrm{mg} / \mathrm{kg}$ body weight) treated animals was $15.062 \pm 3.028$ and $18.150 \pm$ $2.763 \mathrm{U} / \mathrm{mg}$ protein (Figs. 1 and 2).

The level of hepatic GSH was also elevated significantly $(P<0.01)$ in the extract treated animals

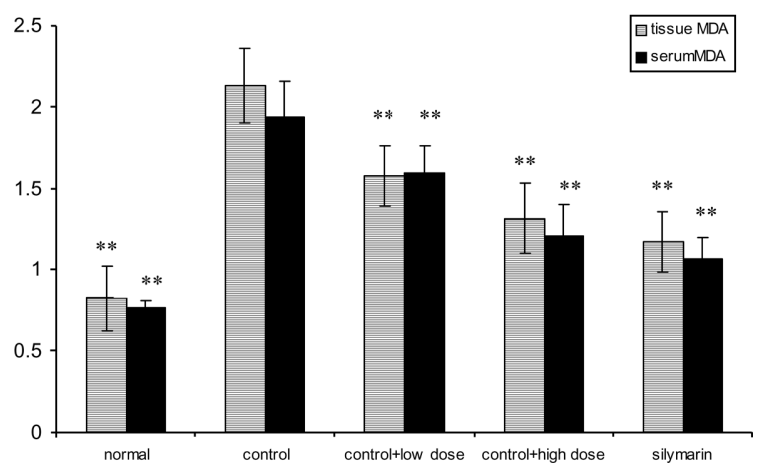

Fig. 1. Effect of ethanol extract on tissue and serum malondialdehyde formation in rats treated with Lagerstroemia speciosa.

prior to the $\mathrm{CCl}_{4}$ challenge compared to the control group ( $5.264 \pm 0.870 \mathrm{nmol} / \mathrm{mg}$ protein) of animal. The concentration at 50 and $250 \mathrm{mg} /$ $\mathrm{kg}$ treated group were $10.318 \pm 1.69$ and $13.286 \pm$ $1.29 \mathrm{nmol} / \mathrm{mg}$ protein which was comparable with the standard drug silymarin13.135 \pm 1.90 nmol/mg protein (Fig. 3). 


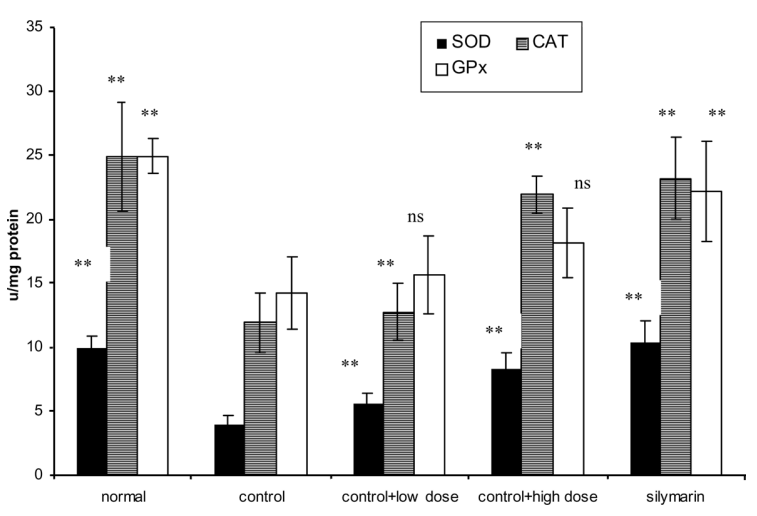

Fig. 2. Effect of alcoholic extract of Lagerstroemia speciosa on tissue SOD, CAT, GPx.

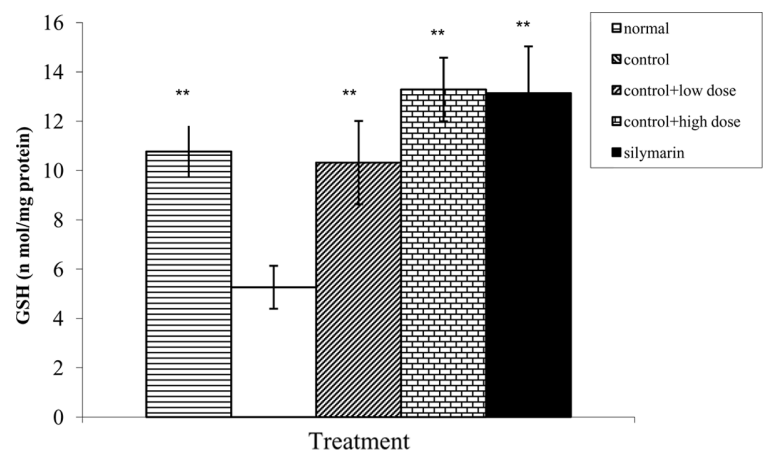

Fig. 3. Effect of L.speciosa on GSH level in liver of carbon tetrachloride induced hepatotoxicity in rats.

\section{DISCUSSION}

Pretreatment of rats with L. speciosa extract dose dependently inhibited the increased level of all hepatic marker enzymes in serum, indicating the liver protective activity of L. speciosa. Stabilization of serum total bilirubin and total protein levels by the pre administration of L. speciosa extract to rats, dose dependently for 7 days prior to the $\mathrm{CCl}_{4}$ administration is a clear indication of the improvement of functional status of the hepatic cells (Brent and Rumack, 1993). The increase in the levels of serum bilirubin reflected the level of jaundice and increase of transaminases and ALP was the clear indications of cellular leakage and loss of functional integrity of cell membrane (Saraswat et al., 1993). The hepatotoxicity by $\mathrm{CCl}_{4}$ is a result of reductive de halogenation, which is catalyzed by cytochrome $\mathrm{P}$ -
450 and forms the highly reactive trichloromethyl free radical $\left(\mathrm{CCl}_{3}-\right)$. This then readily interacts with molecular oxygen to form the trichloromethyl peroxy radical ( $\left.\mathrm{CCl}_{3} \mathrm{OO}-\right)$ (Williams and Burk, 1990). This also forms covalent bond with sulfhydryl group of several membrane molecules like glutathione, which is considered as the initial step in the chain of events leading to lipid peroxidation and hepatic tissue destruction (Lee et al., 2004). Both radicals are capable of binding to proteins or lipids or of abstracting a hydrogen atom from a unsaturated lipids, which initiate lipid peroxidation and liver damage and by play a significant role in the pathogenesis of diseases (Kaplowitz et al, 1986).

The lipid peroxidative degradation of biomembranes is one of the principle causes of hepatotoxicity induced by toxins (Jadon et al., 2004). Lipid peroxidation is viewed as a complicated biochemical reaction involving free radicals, oxygen, metal ions and they host of other factors in the biological system. Since a lipid constitutes nearly $60 \%$ of the compounds in biomembranes, only major perturbation is bound to affect structure and function of the cell. The extract demonstrated potent superoxide and other free radical scavenging property (Priya et al., 2007). Therefore it may be inferred that anti oxidant property of the extract may prevent the formation of trichloro methyl peroxide radical. Thereby inhibit the lipid peroxidation and offer hepatoprotection against $\mathrm{CCl}_{4}$ challenge. Extent of decrease in tissue GSH and tissue lipid peroxidation is a measure of tissue destruction (Bindu and Philip, 2001). Prevention of tissue GSH depletion by the extract treatment also indicates the natural inbuilt tissue protective mechanism is kept intact and oxidative degeneration of tissue is prevented.

Alteration in the activity of alkaline phosphatase may be due to the disturbance in the secretary activity or in the transport of metabolites or may be due to altered synthesis of certain enzymes after $\mathrm{CCl}_{4}$ administration. Erythrocytes are regularly subjected to high oxygen tension as they are among the first cells exposed to exogenous oxidative 
substance that are ingested, injected or inhaled (Halliwell and Gutteridge., 1985).

Plant constituents like triterpenoids and flavonoids are well known for their antioxidant and hepatoprotective activities (Alex et al., 2004). The phytochemical analysis of ethanol extract of $L$. speciosa revealed the presence of saponins, tannins, glycoside and flavonoids etc. The present findings provide pharmacological evidence to the ethnomedicinal property of $L$. speciosa in treating acute jaundice.

\section{REFERENCES}

Aebi H. (1983) Catalase. In: Bergmeyer HU (ed). Methods in Enzymatic analysis, New York, Academic Press. 3, 276-286.

Alex HJ, Dulce HSS, Luciano ML, Vanderlan da SB, Maysa F. (2004) Antioxidant phenolic and quinonemethide triterpenes from Cheiloclinicum cognatum. Phytochem. 65, 1977-1981.

Babu BH, Shylesh BS, Padikkala J. (2001) Antioxidant and hepatoprotective effect of Acanthus ilicifolius. Phytother. 72, 272-276.

Bindu PC, Philip B. (2001) Surfactant- induced lipid peroxidation in a tropical euryhaline teleost oreochromis mossambicus (Tilapia) adapted to fresh water. Indian J. Exp. Biol. 39, 118-123.

Bishayee A, Sarkar A, Chatterjee M. (1995) Hepatoprotective activity of carrot (Daucus carota L) against carbon tetra chloride intoxication in mouse liver. J. Ethnopharmacol. 47, 69-74.

Brent JA, Rumack BH. (1993) Role of free radicals in toxic hepatic injury II. Clin. Toxicol. 131, 173-196.

Diadelis R, Shahrzad T, Rene D, Asghar AH, Peter JO. (2005) Preventing hepatocyte oxidative stress cytotoxicity with Mangifera indica L extract (vimang). Drug. Metabol. Drug. Inter. 21, 19-29.

Halliwell B, Gutteridge JM. (1985). Free radical and toxicology. In: Free radicals in Biol and Med. Clarendon Press, Oxford 206-243.

Harborne JB. (1998) Phenolic compounds, In: Phytochemical methods. Rajkamal Electric press, Delhi 3, 40-42.

Jadon A, Bhadauria M, Shukla S. (2004) 3,4,5Trihydroxy benzoic acid and Terminalia Belerica: A Hepatoprotective Study. Indian Drugs 42, 136-142.
Judy WV, Hari SP, Stogsdill WW, Judy JS, Naguib YM, Passwater R. (2003) Antidiabetic activity of a standardized extract (Glucosol) from Lagerstroemia speciosa leaves in Type II diabetics (a dose dependent study), J. Ethnopharmacol. 87, 115-117.

Kaplowitz N, Aw TY, Simon FR, Stolz A. (1986) Drug induced hepatotoxicity. Ann Int Med. 104, 826-839.

King J. (1965) The hydrolases-acid and alkaline phosphatase In: Van, D.(Ed), Practical Clinical Enzymology. Nostrand company Ltd., London. 191-208

Kirtikar KR, Basu BD. (1987) Indian medicinal plants. International Book Distributors and Book sellers, Dehradun, India. 2, 372-375.

Lee KJ, Eun-Rhan W, Choi CY, Shin DW, Lee DG, You HJ. (2004) Protective effect of acetoside on carbon tetra chloride induced hepatotoxicity. Life. Sci. 74, 1051-1055.

Liu F, Kim J, Li Y, Liu X, Li J. Chen X. (2001) An extract of Legerstroemia speciosa L. has insulin-like glucose uptake-stimulatory and adipocyte differentiationinhibitory activities I 3T3-L1 cells. J. Nutr. 131, 22422247.

Lowry HD, Rosenberg NJ, Farr AL, Randa RJ. (1951) Protein measurement with folin phenol reagent. J. Biol. Chem. 193, 265-275.

Malloy HT, Evelyn KA. (1937) The determination of bilirubin with the photoelectric colorimeter. J. Biol. Chem. 117, 481

McCord JM, Fridovich I. (1969) Superoxide dismutase: an enzymatic function of erythrocuprein. J. Biol. Chem. 244, 6049-6055.

Moron MA, De Pierre JW, Mannervick B. (1979) Levels of glutathione, glutathione reductase and glutathiones-transferase activities in rat liver. Biochem. Biophys. Acta. 582, 67-68.

Ohkawa H, Ohishi N, Yagi K. (1979) Assay for lipid peroxides in animal tissues by thiobarbituric acid reaction. Anal. Biochem. 95, 351-358.

Paglia DE, Valentine WW. (1967) Studies on the qualitative and quantitative characterization of erythrocytes glutathione peroxides. J. Lab. Clin. Med. 70, 158-159.

Priya TT, Sabu MC, Jolly CI. (2007) Amelioration of cisplatin induced nephrotoxicity in mice by ethyl acetate extract of Lagerstroemia speciosa L. J. Basic. Clin. Physiol. Pharmacol. 18, 289-298.

Reitman S, Frankel AS. (1957) A colorimetric method 
for the determination of serum glutamic oxaloacetic and glutamic pyruvic transaminases. Am. J. Clin. Pathol. 28, 56-63.

Saraswath B, Visen PK, Patnaik GK, Dhawan BN. (1993) Anticholestic effect of Picroliv, active hepatoprotective principle of Picrorhiza kurrooa against $\mathrm{CCl}_{4}$ induced cholestasis. Indian. J. Exp. Biol. 31, 316-318.

Satoh K. (1978) Serum lipid peroxide in cerebrovascular disorders determined by a new colorimetric method. Clin. Chem. Acta. 90, 37-43.

Senthilkumar KTM, Rajkapoor B, Kavimani S. (2005)
Protective effect of Enicostemma littorale against CCl4 induced hepatic damage in rats. Pharm. Biol. 43, 485-487.

Seth UK, Dadkar NK, Kamat UG. (1972) Selected topics in experimental pharmacology. Kothari Book Depot, Bombay, India. 1, 126.

Subramoniam A, Evans DA, Rajasekharan S, Pushpangadan P. (1998) Indian. J. Exp. Biol. 36, 385-386. Williams AT, Burk RF. (1990) Carbon tetra chloride hepatotoxicity: An example of free radical mediated injury. Seminars in liver disease 10, 279-284. 